\title{
BOAS NOVIDADES EM QUÍMICA NOVA
}

As atividades acadêmicas, que foram duramente impactadas pela COVID-19, estão próximas da normalização. Neste sentido, é importante ressaltar que nem mesmo o momento de pandemia impediu a comemoração do 43ํano da existência da exitosa Revista Química Nova $(Q N)$, uma luz nesse momento singular. Apesar das dificuldades durante a pandemia, com o auxílio dos assessores, Editores Associados, Editoria, Publisbq e Diretoria da Sociedade Brasileira de Química, $Q N$ publicou regularmente, sem atrasos, os fascículos nas seções Artigos Originais, Revisões, Notas Técnicas, Assuntos Gerais e Educação. Os manuscritos publicados, ininterruptamente desde janeiro de 1978, constituem-se um grande compêndio na área da química para a comunidade. ${ }^{1}$ Em sua trajetória várias mudanças foram introduzidas na revista, além disso, sua adesão na biblioteca de periódicos do SCIELO e a alta visibilidade a partir da indexação no Scopus, Web of Science, PubMed, CaPlus/SciFinder, entre outras bases de dados, permitiram transformar nosso periódico num veículo de alcance mundial.

Nesse ano a Química Nova sofreu algumas mudanças em sua equipe editorial, primeiramente a Profa. Susana I. Córdoba de Torresi que contribuiu com nosso periódico por duas décadas retirou-se do corpo de Editores. Assim, gostaríamos de destacar e agradecer o grande trabalho realizado pela Profa Susana. Ela foi incansável na Editoria não só pela busca de recursos de modo a viabilizar os custos das edições, como também na representação de nosso periódico no Scielo o que deixa toda a Editoria de $Q N$ em débito com a professora Susana. Durante esta trajetoria novas ideias têm sido implementadas, como exemplo destacamos que a partir do fascículo 04 do volume 43 os Editores associados têm selecionado um artigo, dentre as diversas subáreas da química, e divulgado como "Escolha dos Editores". O objetivo, além do reconhecimento aos autores, é apresentar novidades recentes na área do conhecimento do manuscrito. Além disso, para permitir uma maior visibilidade de nossa publicação, os lançamentos dos fascículos também estão sendo divulgados nas diferentes redes sociais, além dos canais oficiais. Para isso, contamos com um Editor associado específico interagindo com os autores, editoria e mídias. O Prof. Dr. Boniek G. Vaz - Universidade Federal de Goiás Brasil é o responsável por essa área de divulgação, e nesse momento gostaríamos que recebesse as boas-vindas ao time da Editoria.

Os frutos estão sendo colhidos como resultado do trabalho profis- sional e acadêmico que têm sido desenvolvidos. Assim, o Fator de Impacto de Química Nova passou para 0,961. O Journal of Citation Reports registrou um incremento considerável no FI quando comparado com os valores dos anos 2016-2019 (0,567-0,668, respectivamente). É digno de nota que não só artigos originais e revisões têm sido publicados, mas qualquer outro assunto relacionado com a Química e Política científica, em Português, Inglês ou Espanhol. Esse incremento no FI demanda que os manuscritos submetidos necessitam continuar a ser avaliados de maneira criteriosa, tanto pelos assessores quanto pelos Editores associados, pois somente assim manteremos essa tendência de alta nessa métrica.

Outro ponto a se destacar é o número de acessos, tanto na forma de HTML quanto em PDF, é outra métrica que demonstra de modo claro a importância de nossa revista. Nos gráficos abaixo, obtidos a partir do portal da Scielo, pode-se verificar a importância de nosso periódico para a comunidade acadêmica. Em média ocorrem cerca de 300 mil acessos mensais. Assim, o formato acesso livre que Química Nova oferece, desde o início da publicação dos fascículos on line, um retorno que a Sociedade Brasileira de Química dá para toda sociedade.

Por fim, a Editoria entende que o aumento do fator de impacto e consequentemente do percentil de Química Nova, continua sendo um desafio para toda nossa comunidade acadêmica. Por isso é importante que os trabalhos publicados sejam citados pelos colegas nas suas diversas publicações. Uma revista que publica em língua portuguesa também pode ser de alta qualidade, mas, para isso, a participação dos autores, assessores e Editoria é um ponto importante a se destacar para o sucesso absoluto.

\section{Giovanna Machado Jorge M. David Nelson H. Morgon Editores de QN}

\section{REFERÊNCIA}

1. Torresi, S. C. I.; Pardini, V. L.; Ferreira, F. V.; Pinto, A. C.; Andrade, J. B.:Quim. Nova, 2005, 28, 745.

Total accesses by year and month Química Nova

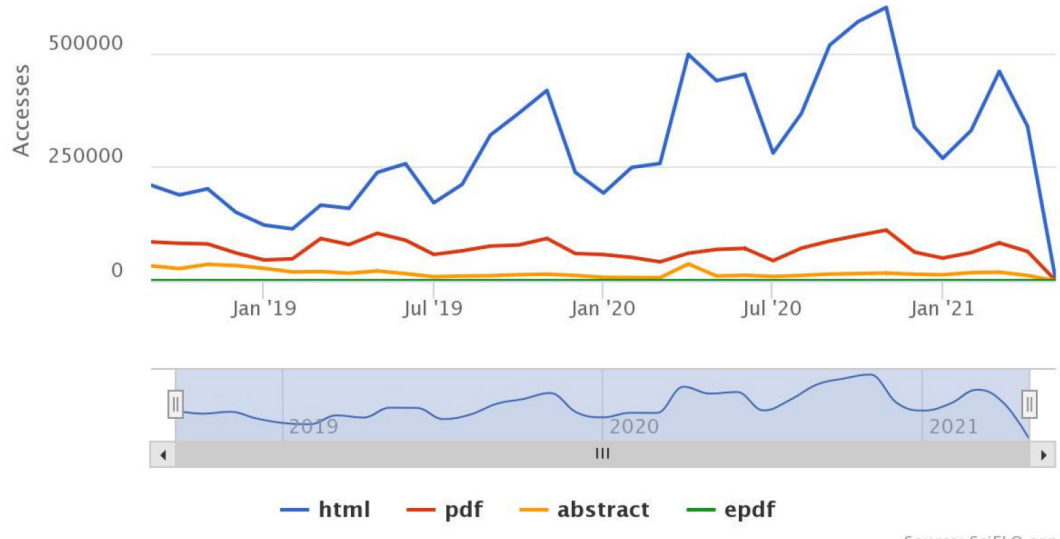

